\title{
Recurrence Rate of Surgical Resection with Reconstruction of Plate Osteosynthesis in the Ameloblastoma Treatment
}

\author{
Suha Mohammad Sami \\ Professor, Department of Maxillo Facial Surgeon, College of Dentistry, University of Kufa, Najaf, Iraq
}

\begin{abstract}
This study was conducted to treat patients with primary ameloblastoma and solid/multicystic ameloblastoma histopathologically. Twenty-seven patients with primary ameloblastoma were treated in the period between 2008 and 2019 in the Department of Oral and Maxillofacial Surgery, and these patients ranged from 16 $\mathrm{y}$ to $58 \mathrm{y}$ old and the average age was $37 \mathrm{y}$. The number of males reached 16 individuals and the number of females 11 individuals. Twenty-two patients with solid/multicystic ameloblastoma histopathologically were treated for partial jaw excision along with the restoration of bone plate osteosynthesis and $2 \mathrm{~cm}$ was used to remove a surgical free margin with bone correction, and three patients with bone metastasis were treated with excision, and the marginal jaw was removed with a $1 \mathrm{~cm}$ free margin with a reconstructive bone structure. Patients with unicystic ameloblastoma were treated through partial removal of the lower jaw with bone structure with titanium, and $1.5 \mathrm{~cm}$ was used as a free margin useful for bone health. There are 3 patients out of twenty-two infected primary solid/multicystic ameloblastoma were present with cases of repeated visualization of radiation are sick after $7 \mathrm{y}$ of surgery and during routine follow-up, one patient was offered during the $6 \mathrm{y}$ after the operation.
\end{abstract}

Keywords: Surgical resection, reconstructive plate, ameloblastoma, radioactive tumor.

\section{Introduction}

The odontogenic benign epithelium neoplasm behaves as a radioactive tumor that can expand but grow slowly. It is worth noting that there are several factors help in inflammation, tooth decay, nutritional deficiency, and indefinite irritation from extraction. Benign toxic epithelial neoplasms act as an expanding, but slow-growing, radioactive tumor. They occur largely in the posterior regions of the lower jaw and tend to recur again unless they are insufficiently removed. It should be made clear that ameloblastoma makes up 14\% of odontogenic tumors of the mandible and maxilla ${ }^{[1]}$. Aggressive growth is nothing but a local invasion, with $70 \%$ of cases turning into malignant tumors and $2 \%$ of

\footnotetext{
Corresponding Author: Suha Mohammad Sami

Professor, Department of Maxillo Facial Surgeon, College of Dentistry, University of Kufa, Najaf, Iraq e-mail: suhsam202@gmail.com
}

them are considered tumors ${ }^{[2]}$.Many previous studies have proven that the age of these patients ranges from thirty to sixty years ${ }^{[3]}$.Also, it appears from $10 \%$ to $15 \%$ of ameloblastoma lesions that appear in childhood and form a high percentage of $25 \%$ in Asia and Africa ${ }^{[4]}$. So histology of ameloblastoma tissue is very similar to enamel organ, which forms teeth ${ }^{[5]}$.Many theories assume inflammation, shock, and tooth decay ${ }^{[6]}$. However, the reason for this stems from a lack of nutrition, unspecified irritation from extraction, or fever, which may lead to a disruption in the growth of dental bud; however, there is a great similarity between dental bud and ameloblastoma in cytokine expression ${ }^{[7]}$.Another theory centered on the morphological differentiation of ameloblasts from pre-ameloblasts, which originally came from the development of the bell stage ${ }^{[8]}$.However, the stratum intermedium will prevent the formation of ameloblasts at the bell stage ${ }^{[9]}$. However, the stellate reticulum will later dissolve to form a very fine sac of tumor nests, which later formed a larger area of cysts that would later be given ameloblastoma multicystic appearance ${ }^{[10]}$. The molecular pathogenesis of ameloblastoma occurs 
due to a defect in the mitogen-activated protein kinase (MAPK) pathway ${ }^{[6]}$, BRAF, a serine- threonine protein kinase activating the MAPKERK signaling pathway has been implicated in $63 \%$ of ameloblastoma ${ }^{[11,12]}$. However, BRAF at codon 600 mutations ${ }^{[13]}$ and BRAF protein mutations will later turn into neoplasm ${ }^{[14]}$. NonMAPK signaling genes like G protein-coupled receptor, smoothened (SMO), and SHH signaling pathway in affected ameloblastoma ${ }^{[15]}$. Likewise, mutations in genetic factors and the consequent cases of differentiation and formation of teeth, which are extremely important for dental development, have been involved in the development of ameloblastoma ${ }^{[16]}$. According to the World Health Organization report centered on dental tumors, which were classified according to the biological behavior of benign and malignant ameloblastoma ${ }^{[7]}$. In each of these tumors, there is a difference in pathological anatomy and anatomical location. There is solid/multicystic ameloblastoma ${ }^{[17]}$, peripheral (or extraosseous) ameloblastoma, andunicystic ameloblastoma.As for malignant ameloblastomas, it will be divided according to the order of frequency, primary ameloblastic carcinoma ${ }^{[7]}$, metastasizing ameloblastoma (secondary peripheral ameloblastic carcinoma), and secondary intraosseous ameloblastic carcinoma.On the other hand, the traditional solid or polycystic form is approximately $91 \%$, and this will display both follicular and plexiform types. In this context, the unicystic ameloblastoma is the second most common benign tumor, accounting for $5-15 \%$ of all types ${ }^{(18)}$. There are two types of parietal and glossy pathological tissues, which show that there are plexiform and follicular patterns ${ }^{[19]}$. It is worth noting that the diagnosis of malignant ameloblastoma is made by functional imaging that combines both PETCT, which is used to study the infiltration of soft tissues and metastasis and imperative for histopathological examination and subtype. The epithelium of ameloblastoma may arise from epithelial cell rest of Malassez, or epithelial lining of a dentigerous cyst or cells of a sheet of Hertwig's or may arise from heterotopic epithelial cells of other organs like the pituitary gland ${ }^{[20]}$. Ameloblastoma treatment may be through surgical or non-surgical type, and from the surgical point of view, this may be conservative or maybe radical surgery. But the approach to conservative surgery is enucleation and cauterization, curettage, cryotherapy, or marsupialization. This method is extremely important because it maintains tissue in its natural form and reduces facial deformation but is associated with a high recurrence rate, especially for the aggressive type ${ }^{[21]}$.
As for the frequent type of aggressive and biological treatment, it would be better if the block resection was performed with free save margins and reconstruction of the defect by grafts ${ }^{[2]}$.Therefore, the rate of treatment and recurrence ${ }^{[23]}$ in this is illustrated by clarifying what are the clinical features and aggressive histological pattern.But aggressive surgical treatment with peripheral ameloblastoma will reduce the frequency of irrespective of age ${ }^{[24]}$. The localized invasion of ameloblastoma leads to repeated treatment after recurrence, and the reason for this is due to the way the patient provides treatment early, which means that the approach to treatment is represented by the presence of different tissue variables or because of the presence of pituitary tumor cells at the site of surgery, especially in solid places, polycystic, and conventional and luminal unicystic type if treated by conservative surgery ${ }^{[25]}$. Whereas, solid/multicystic ameloblastoma and malignant ameloblastoma are much higher ${ }^{[26]}$. The main objective of this study was to study the results of repeated ameloblastoma treatment by surgical resection en bloc tumor with wide bone margin and the use of bone reconstructive plate osteosynthesis.

Data collected to serve the study goals includesex, age, clinical findings, the progression of the tumor, abnormalities of the face and jaw, imaging findings to detect extension of lesion, management, histopathological pattern, clearance of surgical margins, length of follow-up, and time to recurrence. While the patients were diagnosed through a histopathological examination, this was based on what the World Health Organization attached to the tissue type. The treatment is the partial excision of the procedure with a free safety margin because of the high probability of regional invasion. It must be clarified and indicated that the bone margin represents the distance from the radiographic margin, which is expected to be free of diseases and tumors to conduct bone operations. Often, the healthy mucosa covering the cortical hole is removed as a margin. The bone margin is $10-15 \mathrm{~mm}$ for benign unicystic ameloblastoma and 15-20 mm for solid/multicystic type and resection with marginal amandiblactomy for peripheral ameloblastoma, with bony defect reconstructions through reconstructive bony plate osteosynthesis $^{[27]}$.

\section{Results}

The results of this study showed that the number of male patients was 16 , and they constituted $59.3 \%$ of the total patients were in this study. The number of female 
patients was 11 , which constituted $40.7 \%$ of the total number of patients in this study.As for the age of the patients were in this study, which ranged from 16 to 58 years, but the majority of the ages were between 30 and 39 years, which constituted $44.5 \%$ (Table 1 ). Twentytwo patients were histopathologically treated by partial resection of the lower jaw, along with the completion of the restorative bone-building process. This purpose of about $2 \mathrm{~cm}$ was used to remove a surgical free margin with bone correction. Three patients had an extraosseous type of ameloblastoma and those were treated by soft tissue excision and marginal mandibular resection were treated with a portion of the free margin equivalent to 1 $\mathrm{cm}$ of muscle with the bone, with reconstructive bone plate osteosynthesis, besides that it applying a bone repair process(Figure 1a-f).
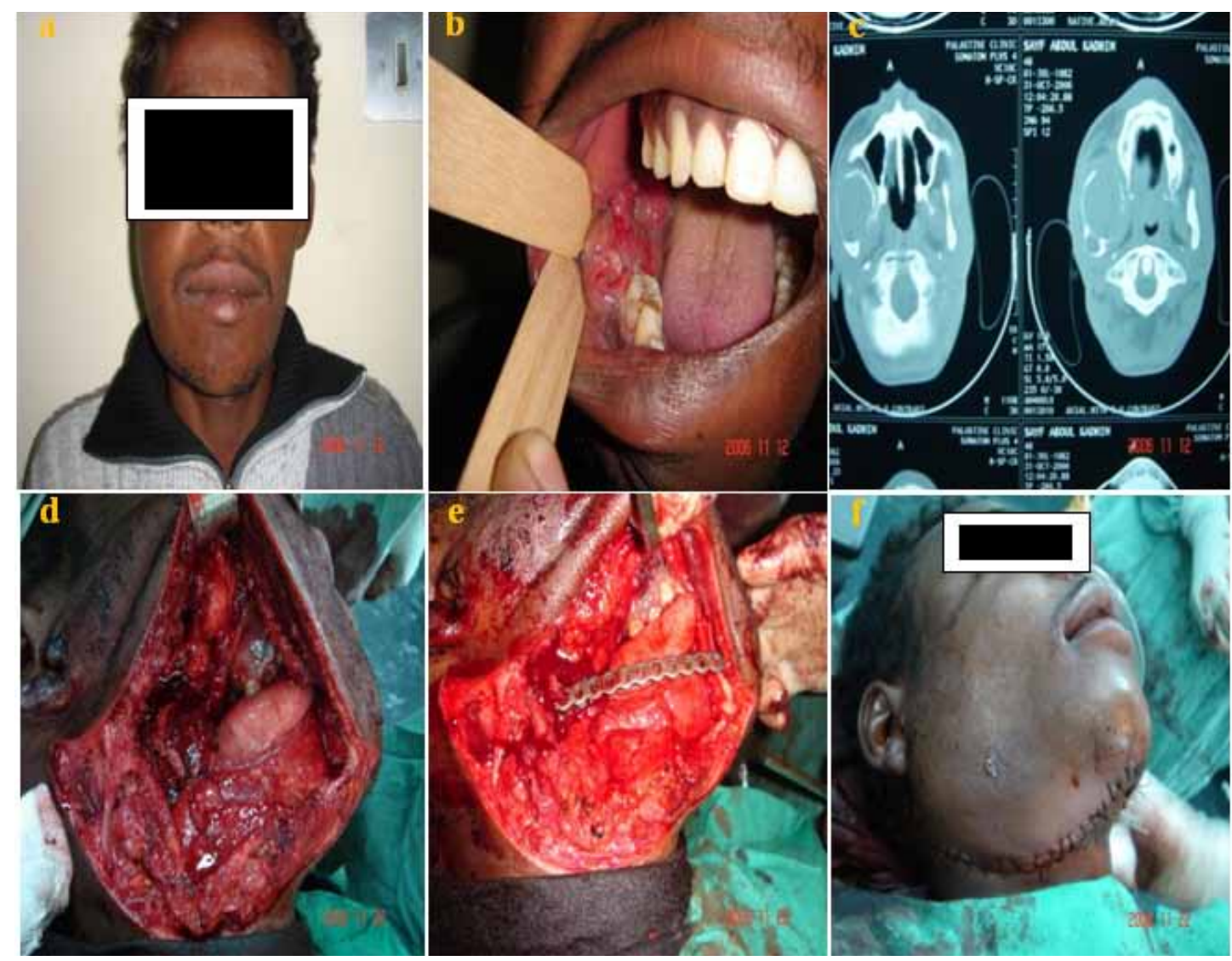

Figure 1: (a) Extraoral swelling. (b) Intraoral tumor. (c) Axial CT.(d) Mandibular segmental resection. (e) Performed reconstructive plate. (f)Postoperatively

The results showed that two patients had unicystic ameloblastoma and were treated by segmental resection of the mandible with titanium reconstructive bone plate osteosynthesis; thus, $1.5 \mathrm{~cm}$ was used as a margin with some health of bone (Table 2).

Table 2: Distribution of ameloblastoma and type of surgery with a recurrence rate

\begin{tabular}{|l|c|l|c|c|}
\hline Type of ameloblastoma & $\begin{array}{c}\text { No. of } \\
\text { Patients }\end{array}$ & Type of Surgery & $\begin{array}{c}\text { Free Margin } \\
\text { (cm) }\end{array}$ & $\begin{array}{c}\text { Recurrence } \\
\text { Rate }\end{array}$ \\
\hline Extra osseous ameloblastoma & 3 & Marginal mandibulectomy Resection of soft tissues. & 1 & 1 \\
\hline $\begin{array}{l}\text { Solid/multicystic } \\
\text { ameloblastoma }\end{array}$ & 22 & Segmental resection+ titanium Reconstructive bone plate. & 2 & 3 \\
\hline Unicystic ameloblastoma & 2 & Segmental resection+ titanium Reconstructive bone plate & 1.5 & 0 \\
\hline Total & $\mathbf{2 7}$ & & & $\mathbf{4}$ \\
\hline
\end{tabular}


The patients were present in this study were monitored regularly by ten-eleven years clinically and radiographically to detect recurrence. The results of the study revealed that three of the patients complained of the repetition of ameloblastoma type solid/multicystic radiographically, but there was one patient appeared in the frequency of radiography whose primary type was an extraosseous type of ameloblastoma (Figure 2).

Extra osseous ameloblastoma

Solid/multicystic ameloblastoma

\section{Unicystic ameloblastoma}

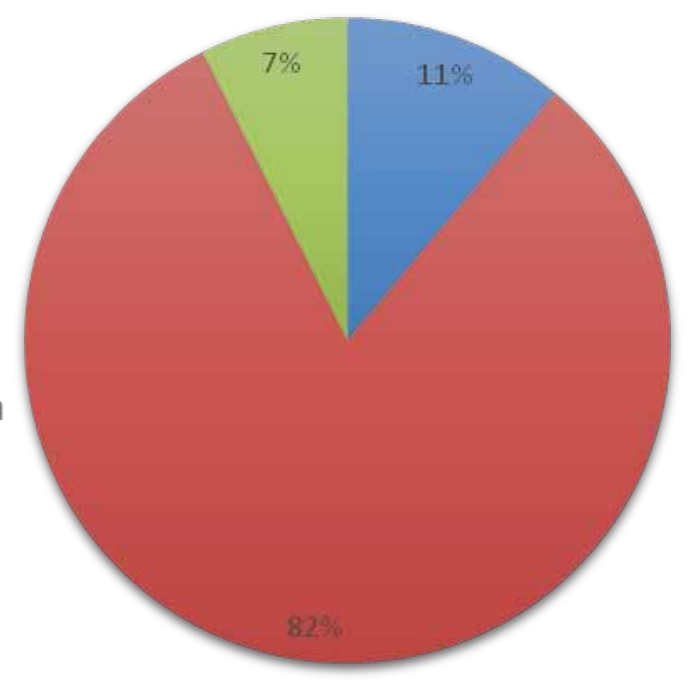

Figure 2: Ameloblastoma vs. number of patients

Two patients received surgery during routine follow-up after seven years, and there is one patient came six years after the operation. Also, there was one patient suffered from primary peripheral ameloblastoma (extraosseous) after nine years of surgery, and that there were four patients were presented with twenty-seven were operated as primary ameloblastoma, the recurrence rate was $(14.8 \%)$.

\section{Discussion}

Admantinoma is considered a dental polyp, and this is what Ivory and Churchill called what is known as ameloblastoma $^{[28]}$. As for the results that have to do with the age group, according to what was mentioned in this study, the average age ranged 30-39 years. This is in line with Fatemah Faras et al. (2017) study, which stated that the average age was 20-40 years, while the age group that was present in Andrew (2015) ${ }^{[27]}$ study ranged 3060 years, i.e. ameloblastoma It was introduced during the third and fourth decades of life ${ }^{[17]}$. In this study, radical surgery was addressed with appropriate margins, so that twenty-two patients with solid/multicystic ameloblastoma were treated through partial removal of the lower jaw with the completion of the restoration and bone-building process, as $2 \mathrm{~cm}$ was used as an important surgical free margin to maintain bone health. Three patients were suffering from an extraosseous type of ameloblastoma, and those treated with resection of soft tissues and marginal mandibulectomy with a $1 \mathrm{~cm}$ free margin part of the muscle that communicated with the lesion was removed with the bone, with reconstructive bone plate osteosynthesis was applied. Likewise, the results of the study showed that there are two patients with unicystic ameloblastoma were treated by segmental resection of the mandible with titanium reconstructive bone plate osteosynthesis so that $1.5 \mathrm{~cm}$ was used as an important margin for dental health.

\section{Conclusions}

The treatment depends on several factors, the most important of which is the aggressiveness of the tumor, duration, extent, size, histopathological type, and radiographically appearance, especially if the radiation is multi-site while maintaining an indefinite margin. As for the recurrence of occurrence, it depends on the age of the patient, anatomical site, molecular histopathology, genetic mutation, and/or density of bone, which is the main barrier to the repetition of the local area, so aggressive surgery is a good indicator of removing the tumor. Also, the frequency is affected by the type of molecular etiological cause, how early patientsreceive treatment, and type of surgery affected the recurrence rate of ameloblastoma. 
Ethical Clearance: This study was approved by the Ethics Committee, University of Kufa. The study protocol was thoroughly explained for using samples of patients and written informed consents were obtained from them prior to participation in the study. This investigation was done according to the principals of the Declaration of Helsinki. All patients were informed about the aims and protocol of the study.

Source of Funding: By Self

\section{Conflict of Interest: Nil}

\section{References}

1. Oginni FO, Stoelinga PJ, Ajike SA, Obuekwe ON, Olokun BA, Adebola RA, et al. A prospective epidemiological study on odontogenic tumours in a black African population, with emphasis on the relative frequency of ameloblastoma. Oral MaxillSurg 2015;44(9):1099-105.

2. DeVilliers P, Suggs C, Simmons D, Murrah V, Wright JT. Microgenomics of ameloblastoma. Dent Resear 2011;90(4):463-9.

3. Oomens MA, Van der Waal I. Epidemiology of ameloblastomas of the jaws; a report from the Netherlands. Medic Oral, Patol Oral Y Cirug Buca 2014;19(6):e581.

4. Bansal S, Desai RS, Shirsat P, Prasad P, Karjodkar $\mathrm{F}$, Andrade N. The occurrence and pattern of ameloblastoma in children and adolescents: An Indian institutional study of 41 years and review of the literature. Oral Maxillof Surg. 2015;44(6):72531.

5. Bassey GO, Osunde OD, Anyanechi CE. Maxillofacial tumors and tumor-like lesions in a Nigerian teaching hospital: an elevenyear retrospective analysis. AfricHeal Scie. 2014;14(1):56-63.

6. Brown NA, Betz BL. Ameloblastoma: a review of recent molecular pathogenetic discoveries. BiomarkCanc 2015;7:BIC-S29329.

7. Sciubba JJ, Eversole LR, Slootweg PJ. Odontogenic tumours. In: Barnes L, Eveson JW, Reichart P, Sidransky D, eds. World Health Organization classification head and neck tumours. 2005, IARC Press: Lyon: p. 283-328.

8. Fan K, Andrews BT, Tabit CJ, Bradley JP. The Sarnat studies in craniofacial biology. Craniof Surg 2012;23(1):37-43.
9. Jussila M, Thesleff I. Signaling networks regulating tooth organogenesis and regeneration, and the specification of dental mesenchymal and epithelial cell lineages. Cold Spring Harbor, Perspect Biol 2012;4(4): a008425.

10. Gupta N, Saxena S, Rathod VC, Aggarwal P. Unicystic ameloblastoma of the mandible. Oral MaxillofPathol 2011;15(2):228.

11. Kurppa KJ, Catón J, Morgan PR, Ristimäki A, Ruhin B, Kellokoski J, Elenius K, Heikinheimo $\mathrm{K}$. High frequency of BRAF V600E mutations in ameloblastoma. Pathol 2014;232(5):492-8.

12. Sweeney RT, McClary AC, Myers BR, Biscocho J, Neahring L, Kwei KA, Qu K, Gong X, Ng T, Jones $\mathrm{CD}$, Varma S. Identification of recurrent SMO and BRAF mutations in ameloblastomas. Natu Genet 2014;46(7):722-5.

13. Fregnani ER, Perez DE, Paes de Almeida O, Fonseca FP, Soares FA, Castro-Junior G, Alves FA. BRAFV600E expression correlates with ameloblastoma aggressiveness. Histopath 2017;70(3):473-84.

14. Niault TS, Baccarini M. Targets of Raf in tumorigenesis. Carcinog 2010;31(7):1165-74.

15. Mishra P, Panda A, Bandyopadhyay A, Kumar H, Mohiddin G. Sonic hedgehog signalling pathway and ameloblastoma-a review. Clinic DiagnoResea 2015;9(11): ZE10.

16. Heikinheimo K, Jee KJ, Niini T, Aalto Y, Happonen RP, Leivo I, Knuutila S. Gene expression profiling of ameloblastoma and human tooth germ by means of a cDNA microarray. Dent Resear. 2002;81(8):52530 .

17. Dias LF, de Araujo Vian RL, Nunes PM, Magalhaes HE, do Carmo CD, Passos EC, Neves LR. Major considerations on the clinical, epidemiological, histopathological and therapeutic aspects of ameloblastomas: a systematic review. HealtScie 2019;13(3).

18. Dhanuthai K, Chantarangsu S, Rojanawatsirivej S, Phattarataratip E, Darling M, Jackson-Boeters L, Said-Al-Naief N, Shin HI, An CH, Hong NT, An PH. Ameloblastoma: a multicentric study. Oral Surg Oral Med Oral Path Oral Radio 2012;113(6):782-8.

19. Wright JM, Odell EW, Speight PM, Takata T. Odontogenic tumors, WHO 2005: where do we go from here? Head and neck pathology 2014;8(4):37382. 
20. Ritchie AC. Boyd's textbook of pathology. Lea and Febiger; 1990.

21. Dandriyal R, Gupta A, Pant S, Baweja HH. Surgical management of ameloblastoma: Conservative or radical approach. Natiomaxillof surg 2011;2(1):22.

22. Shen YF, Rodriguez ED, Wei FC, Tsai CY, Chang YM. Aesthetic and functional mandibular reconstruction with immediate dental implants in a free fibular flap and a low-profile reconstruction plate: five-year follow-up. Annal Plast Surg 2015;74(4):442-6.

23. Huang IY, Lai ST, Chen $\mathrm{CH}$, Chen CM, Wu CW, Shen YH. Surgical management of ameloblastoma in children. Oral Surgery, Oral MedOral Pathol Oral RadiolEndod 2007;104(4):478-85.

24. Hertog D, Schulten EA, Leemans CR, Winters HA, Van der Waal I. Management of recurrent ameloblastoma of the jaws; a 40-year single institution experience. Oral Oncol 2011; 47(2):145-6.
25. Antonoglou GN, Sándor GK. Recurrence rates of intraosseous ameloblastomas of the jaws: a systematic review of conservative versus aggressive treatment approaches and meta-analysis of non-randomized studies. Journal of CranioMaxillofacial Surgery. 2015;43(1):149-57.

26. Zhang B, Zhang J, Huang HZ, Xu ZY, Xie HL. Expression and role of metalloproteinase-2 and endogenous tissue regulator in ameloblastoma. Oral Pathol Medic 2010;39(3):219-22.

27. McClary AC, West RB, McClary AC, Pollack JR, Fischbein NJ, Holsinger CF, Sunwoo J, Colevas AD, Sirjani D. Ameloblastoma: a clinical review and trends in management. Europ Arch Oto-RhinoLaryng 2016;273(7):1649-61.

28. Hariram SM, Malkunje LR, Singh N, Das S, Mehta G. Ameloblastoma of the anterior mandible. NatiMaxillof Surg 2014;5(1):47. 